\title{
ДАРХАДЫН ХОТГОРЫН ХУРДАС ХУРИМТЛАЛЫН ОРЧИН, УУР АМЬСГАЛЫН ОНЦЛОГИЙГ БИОГЕОХИМИЙН СУДАЛГААНЫ АРГААР ТОДОРХОЙЛОХ НЬ
}

\author{
Ц.Оюунчимэг ${ }^{1}$, С.Кривоногов \\ ${ }^{1}$ ШУА-ийн Геологи, эрдэс баялгийн хүрээлэн, \\ ияахим шуудан: оуип_tse@yahoo.com \\ ${ }^{2}$ Оросын ШУА-ийн СС-ийн Геологи, минералогийн хүрээлэн
}

\section{Товч агуулга}

Монгол орон нь Ази тивийн муссоны тогтолцооны хойд зах, өрнөдөөс Атлантын агаарын их урсгал зонхилдог Сибирийн эх газрын уур амьсгалын өмнөд зах нийлсэн завсарын бүсд оршдог газар зүйн онцлогтой. Мөн тектоникийн идэвхижил ихтэй Умард Монголын бүс нутаг Дархадын хотгорт мөстлөгийн ул мөр харьцангуй элбэг тохиолдох тул эртний уур амьсгал, байгаль орчны өөрчлөлт, тэдгээрийг сэргээн тодруулах судалгааны ажилд зайлшгүй судлах шаардлагатай объектийн тоонд орно.

Дархадын хотгор нь Байгалийн рифтийн бүсийн баруун өмнөд хэсэгт далайн түвшнээс 1538 м өндөрт оршино. Дархадын хотгорын хэмжээнд одоогоос 100000-95000 жилийн өмнө явагдсан мөстлөгийн хамгийн их түрэлттэй холбоотойгоор мөсөн даланд боогдсон томоохон хэмжээний нуур оршиж байсан нь тогтоогдсон (Дорофеюк ба бусад 1998) бөгөөд хожуу плейстоцены төгсгөл үеэс эхлэн нуурын ус татарч улмаар өөр хоорондоо холбоотой хэд хэдэн нуур үлдсэн нь одоогийн Доод (Доод цагаан) нуур юм. Энэхүү эрдэм шинжилгээний өгүүлэлд Доод нуурын хурдасын литологийн тогтоц болон зарим цөмрөгийн биогеохимийн судалгааны дүнг үндэслэн хурдасын органик бодисын агууламж, тархалтын зүй тогтол, тэдгээрийн эх үүсвэр зэргийг тогтоож улмаар Дархадын хотгорын сүүлийн 14400 жилийн (урьдчилсан байдлаар) уур амьсгал, байгаль орчны өөрчлөлт, тэдгээрээс үүдэлтэй нуурын усны түвшний хэлбэлзэлийг тогтоох оролдлого хийлээ.

Судалгааны материал болох 3 өрмийн цөмрөгийг 2005 онд Монгол-Оросын хамтарсан экспедицийн хүрээнд авсан. Эдгээр цөмрөгийн органик нүүрстөрөгч (ТOC) ба азотын нийлбэр (TN) агуулга, нийлбэр хүхрийн (TS) агуулгыг Elemental Analyzer CHNS-O багажаaр (KORDI) тодорхойлсон. Үүнээс Core-1 өрмийн цөмрөгийн хэд хэдэн интервал дээр үнэмлэхүй нас тодорхойлогдсоноор түүнийг судалгааны голлох материал болгосон. Дээжин дэх органик нүүрстөрөгч болон нийлбэр азотын агуулга нилээд хэлбэлзэлтэй ТОС $1.32 \%-6.59 \%$ ба TN $0.139 \%$ - 0.512\% хооронд байна. Ялангуяа цөмрөгийн дээд талын 300 см-н хурдасд TOC ба TN агуулга харьцангуй өндөр байгаа нь Голоцен буюу одоогоос 10000 жилийн өмнө уур амьсгал дулаан байсныг гэрчилж, харин цөмрөгийн доод хэсгийн 300 см-т тэдгээрийн агуулга буурсаныг тухайн цаг үед хурдас хуримтлалын хоёр өөр орчин нөхцөл байсныг тодорхойлж байна.

ТҮлхүҮр Үгс: Дархадын хотгор; Доод нуур; органик нҮүрстөрөгч ба азотын нийлбэр агуулга; уур амсьгал, байгаль орчньл өөрчлөлт 


\section{ОРШИЛ}

Сүүлийн жилүүдэд далайн болон эх газрын нууруудын тунамал хурдасын биогеохимийн бүрэлдэхүүнийг нарийвчлан судалж эртний уур амьсгал, байгаль орчны өөрчлөлтийг сэргээн тодруулах ажил эрчимтэй хийгдэж байна. Эх газрын томоохон нууруудын нэг болох Байгал нуурын хурдасын судалгаагаар органик бодисын тархалт, тэдгээрийн хувь хэмжээ болон хурдас хуримтлалын орчноос хамаарах хамаарлын талаар ихээхэн өгөгдөлүүд бий болоод байна (Выхристюк., 1980; Watanabe et al., 2003; Matsumoto et al.,2000; 2003; Тани и др, 2001; Prokopenko et al., 2005).

2001 оноос эхлэн энэ чиглэлээр Хөвсгөл нуурын хурдасын судалгааны ажил нилээд өргөн хүрээтэй хийгдэх болсон (Fedotov et al., 2003; Tomurhuu et al.,2003 Oyunchimeg et al., 2004; Nara et al., 2005; Наранцэцэг ба бусад., 2006., Tani et al., 2007; Matsumoto et al., 2007) бөгөөд улмаар Дархадын хотгорын талаар шинэ мэдээлэлүүд бий болоод байна ( Krivonogov et all.,2005;)

\section{СУДАЛГААНЫ АЖЛЫН ТАЛБАЙ}

Доод нуур нь Дархадын сав газарт 2 хэсэгт сунаж тогтсон хэлбэртэй, далайн түвшнээс 1536 м өндөрт оршино. Доод нуур нь Тарган, Дунд болон Хармай нууруудаас бүрдэх бөгөөд 18 км урт, 7 км өргөн, 15 м гүн нуур юм. Нуурт Шишхид, Шаргын болон Арсайн голууд цутгаж нуураас Шишхидийн гол гадагшаа урсана (Уфлянд, 1969). Нуурын эргийн байдал харилцан адилгүй өмнөд эрэг нь уулархаг бөгөөд усны мандалаас 5-12 м өндөр. Харин нуурын баруун хойт, зүүн, зүүн хойт эрэг намхавтар тэгш (Цэрэнсодном Ж. 2000).

Бидний судалгааны объект Дархадын хотгорт кайнозойн янз бүрийн гарал Үүсэлтэй дөрөвдөгчийн хурдасууд өргөн тархсан байдаг. Геофизикийн судалгаагаар хотгорын хойд хэсэгт дөрөвдөгчийн хурдас 200-300 м, өмнөд хэсэгт 400 м зузаантай (Zorin et al., 1989) болох нь тогтоогдсон.

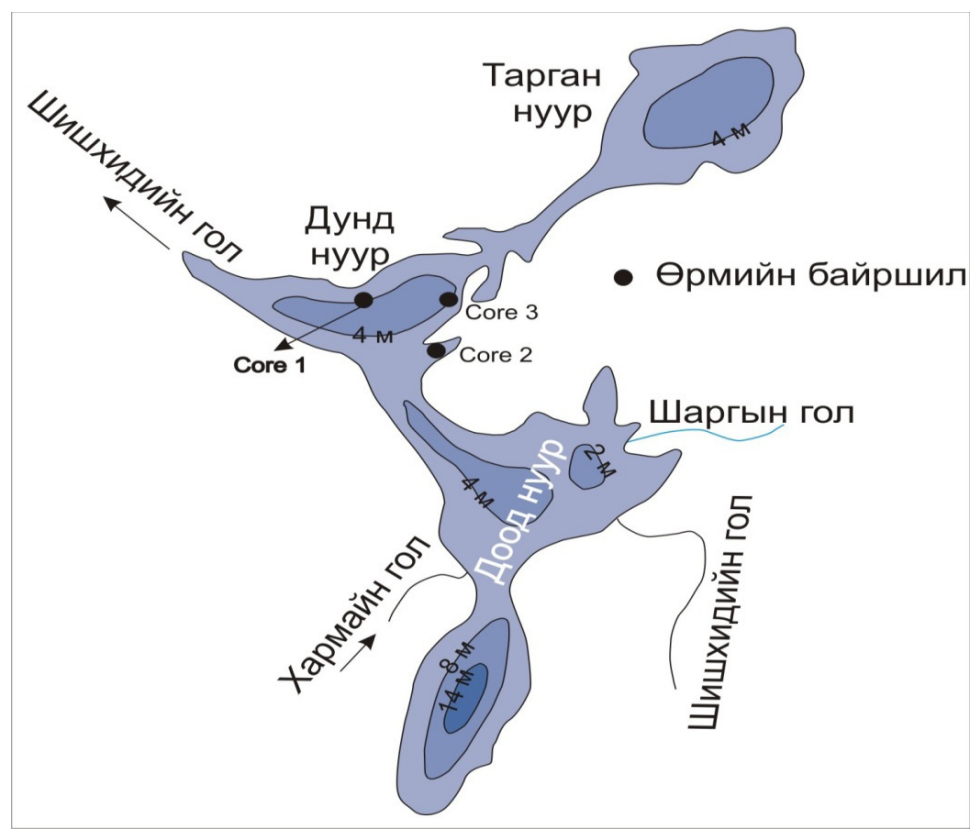

Зураг 1. Доод нуур болон өрмийн иэгийн байршлууд 
СУДАЛГААНЫ МАТЕРИАЛ БА АРГА АРГАЧЛАЛ

Тус судалгааны ажилд Доод нуураас авсан 3 цөмрөгийн литологи болон биогеохимийн шинжилгээний үр дүнг ашигласан. Эдгээр дээжүүдийг хүндийн хүчний аргаар гаргаж авсан бөгөөд цөмрөгүүдийн дугаар, газар зүйн байршил, дээж авсан усны гүн болон цөмрөгийн уртын хэмжээг 1-р хүснэгтэд харуулав.

Судалгааны ажлын явцад Доод нуурын хурдасын Core-1, Core-2, Core-3 цөмрөгийн 150 дээжний биогеохимийн шинжилгээг Солонгос улсын Далай судлал ба Хөгжлийн хүрээлэнгийн (KOPRI) лабораторийн багаж тоног төхөөрөмжийг ашиглан шинжилсэн болно. Үүнд: Органик бус нүүрстөрөгчийн (TIC-total inorganic carbon) хэмжээг UIC CO2 Coulorometer (CM5240), нүүрстөрөгч (TC-total carbon), азот (TN-total nitrogen) болон хүхрийн нийлбэр (TS- total sulfur) агуулгуудыг Flash EA 1112 серийн CHNS-O Elemental Analyzer багажаaр тус тус тодорхойлсон. Хурдсанд агуулагдах нийт органик нүүрстөрөгчийн хэмжээг нийлбэр нүүрстөрөгч болон органик бус нүүрстөрөгчийн зөрүүгээр тодорхойлов (TOC $=$ TC-TIC).

Доод нуурын хурдасын цөмрөгийн дугаар, газар зүйн байршил,

Хүснэгт 1 дээж авсан усны гүн болон ияөмрөгийн уртын хэмжээ

\begin{tabular}{|c|c|c|c|c|}
\hline \multirow{2}{*}{$\begin{array}{c}\text { ЦөмрөгүҮдийн } \\
\text { дугаар }\end{array}$} & \multicolumn{2}{|c|}{ Газар зүйн байршил } & \multirow{2}{*}{ Усны гүн, } & \multirow{2}{*}{ Цөмрөгийн урт, л } \\
\hline & У.Ө & Д.У & & \\
\hline Core-1 & $51^{\circ} 24^{\prime} 26.0^{\prime \prime}$ & $99^{0} 19^{\prime} 30.7^{\prime \prime}$ & 3.5 & 6,23 \\
\hline Core-2 & $50^{\circ} 23^{\prime} 43.4^{\prime \prime}$ & 99021'33.7'” & 3.5 & 3,80 \\
\hline Core-3 & $51^{\circ} 24^{\prime} 03.0^{\prime \prime}$ & $99^{\circ} 21^{\prime} 17.07 "$ & 7.3 & 1,50 \\
\hline
\end{tabular}

\section{СУДАЛГААНЫ АЖЛЫН ҮР ДҮН}

\section{1. Доод нуурын хурдасын литологийн тогтоц ба наснь асуудал}

Доод нуурын хурдасын судалгаанд хамрагдсан цөмрөг 1 ба 2 нь литологийн тогтоц, бүрэлдэхүүний хувьд ялгаатай 4 үндсэн хэсгээс тогтоно (Зураг 2). Үүнд: (доороос дээш) модны нүүрс бага хэмжээгээр агуулсан хар ногоовтор өнгийн нарийн ширхэгтэй элс; зарим хэсэгтээ элсний нимгэн үенцэр бүхий хар ногоон өнгийн зануулаг наанги (ховроор вивианитын толбонуудтай); дун болон ургамлын үлдэгдлээр баялаг, наанги ба элсний нимгэн үенцэр бүхий элсэрхэг зануу; хар ногоон өнгийн зануулаг наанги тус тус ээлжлэн тогтсон байна. Харин цөмрөг 3 нь элсэрхэг зануу ба зануулаг наангийн үенээс тогтоно [Оюунчимэг ба бусад 2009].

Доод нуурын өмнөд хэсгээс авсан зарим цөмрөгийн дээжний насны тодорхойлолтоор Доод нуурын хурдас нь хожуу плейстоцен ба голоцен [Dorofeyuk et al. 1998] болон түрүү ба дунд голоцены [Khosbayr et al.1999] үед хуримтлагдсан талаар зарим хэвлэгдсэн материалуудад дурьдагддаг (Зураг 3).

Бидний судалгаанд хамрагдсан Доод нуурын хурдасын цөмрөг 1-ийн 11 түвшнээс илрүүлсэн модны нүүрс, дун, ургамлын үлдэгдэл бүхий дээжүүдэд АНУ-ын Аризонагийн Их сургуулийн лабораторид цацраг идэвхит нүүрстөрөгчийн аргаар үнэмлэхүй нас тодорхойлсон бөгөөд эдгээрийн дотроос нарийвчлал сайтай зарим өгөгдөлүүдийг ашиглан хурдас хуримтлалын дундаж хурдыг $(0,13 \mathrm{~cm} /$ жил) тооцоолж улмаар насны загварыг урдчилсан байдлаар боловсруулаад байна [Narantsetseg et al.2010]. Энэхүү загварын дагуу Доод нуурын хурдасын цөмрөг 1-ийн хамрах цаг хугацааг хожуу плейстоценоос (620-160 см интервалд 14000-10500 жил) дунд голоцен(160-0 см интервалд 105006000 жил) хэмээн үзсэн бөгөөд харин 
бусад цөмрөгүүдийн хувьд литологийн харьцуулалтын аргыг хэрэглэсэн болно (Зураг 3).

\section{2. Хурдас дахь органик нүҮрстөрөгч} (ТОС) ба азотын (TN) тархалт болон тэдгээрийн харьцаа (ТOC/TN)

Доод нуурын хурдасын цөмрөг 1-ийн органик нүүрстөрөгч ба азотын нийлбэр агуулгын гүний дагуух тархалтыг зураг 4-т харуулав. ЭнэхүY цөмрөгт органик нүүрстөрөгч ба азотын тархалтын муруй ижил зүй тогтолтой бөгөөд агуулга нь 0,80-6,59\% ба 0,11-0,59\% хооронд тус тус хэлбэлзэж байна. Ялангуяа цөмрөгийн дээд хэсгийн элс болон наангийн нимгэн үенцэр бүхий элсэрхэг зануу, зануулаг наангиас тогтсон 300 см-н зузаантай хэсэгт органик нүүрстөрөгч болон азотын нийлбэр хэмжээ нилээд өндөр 2-6\% ба 0.2-0.6\% байгаа бол доод хэсгийн 300 см-т харьцангуй бага дунджаар 0,19-2,36\% ба 0,01-0,21\% хооронд тус тус хэлбэлзэнэ.
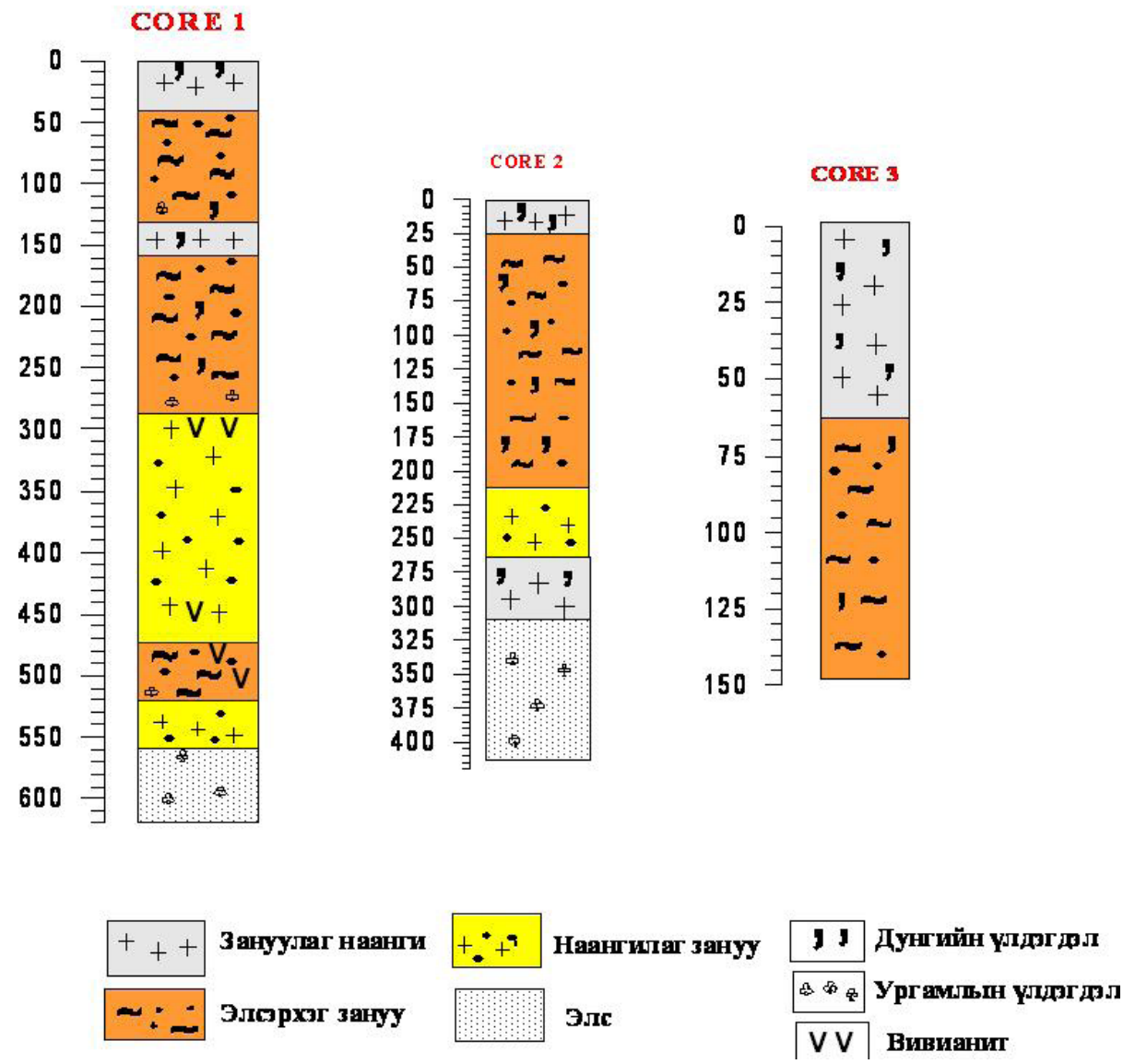

Зураг 2. Доод нуурын хурдасын литологийн тогтои

Доод нуурын хурдасын цөмрөгийн дээд хэсгийн элс болон наангийн нимгэн үенцэр бүхий элсэрхэг зануу, зануулаг наангийн үенд TOC/TN харьцаа дунджаар 11 орчим багаа бол доод хэсгийн нарийн ширхэг бүхий элсний үед энэ харьцаа нилээд өндөр 16-28 хооронд хэлбэлзэж байна (Зураг 5). 
4.3.Хурдсанд агуулагдаххүхэр (TS), органик бус нүҮрстөрөгч (ТIC) болон карбонатын агууламжс

Доод нуурын хурдсанд агуулагдах хүхрийн нийлбэр агуулга нь зүсэлтийн доод хэсэгт харьцангуй бага $0,02-0,05 \%$ хооронд хэлбэлзэж байгаа бол цөмрөгийн гүний 220 см-ээс эхлэн аажмаар нэмэгдэж 0,58\% хүрнэ (зураг 5). Органик бус
нүҮрстөрөгчийн агуулга нүүрстөрөгчийн нийлбэр агуулгын нэгэн адил тархалттай бөгөөд цөмрөгийн $\quad 620-300$ см-ийн интервалд дунджаар $0,35 \%$ байсан бол дээд талын 300 см-ийн интервалд түүний агуулга 8,48\% хүртэл нэмэгдэж байгаа нь хурдасын нүүрстөрөгчийн нийлбэр агуулга нь органик бус нүүрстөрөгчөөр хянагдаж байгааг харуулж байна.
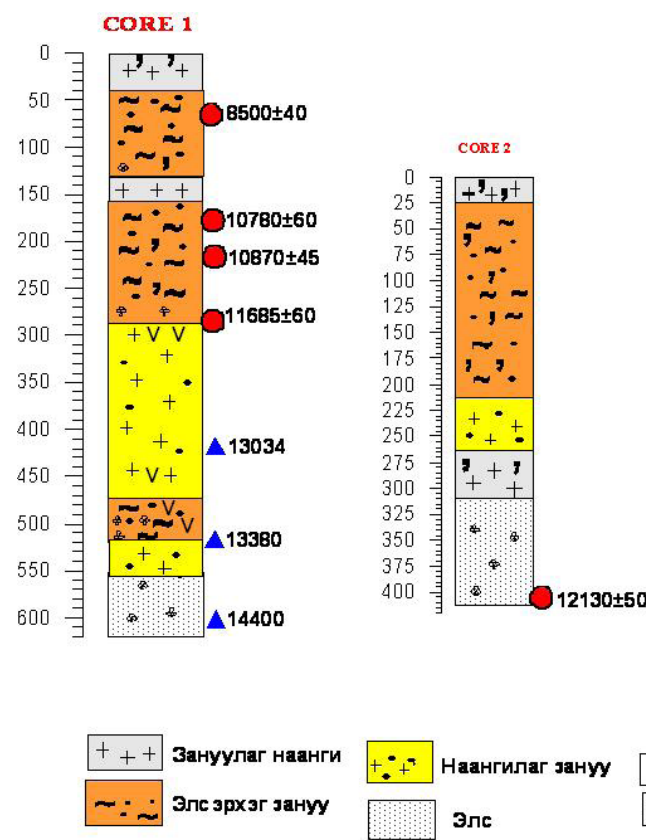

\begin{tabular}{|l|}
\hline ग Дунгийн үлдэгдэл \\
Ургамльн үлдэгдэл \\
\hline
\end{tabular}
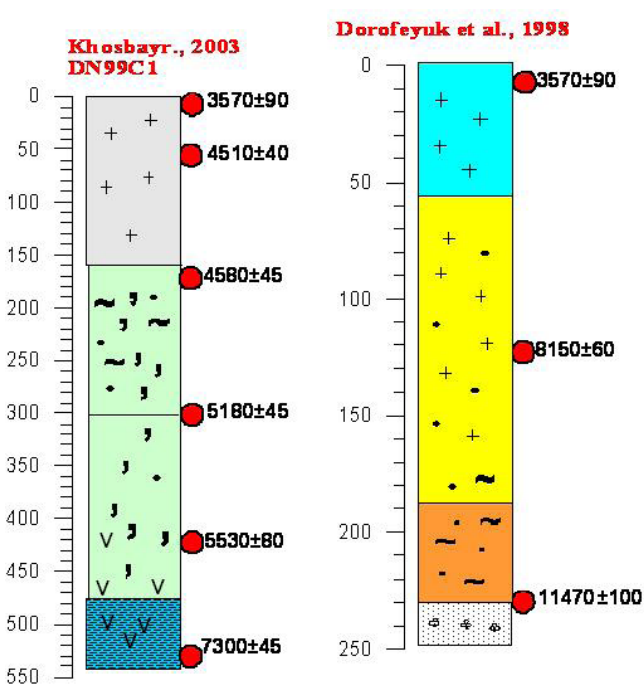

ЦЦацраг идэвхит ${ }^{14} \mathrm{C}$ аргаар тодорхойлсон үнзмлзхүй нас

- ${ }^{14} \mathrm{C}$ аргар тодорхойлсон үнзмпзхүй насны өгогд олүүдийг болевсруулж урьдчилсан байдлаар тодорхойлсон нас

\section{Зураг 3. Доод нуурын хурдсын үнэмлэхүй насны өгөгдөлҮҮд}

\section{4. Доод нуурын хурдасын органик бодисын эх үусвэр}

Нуурын хурдсанд агуулагдах органик бодис нь ихэвчлэн фитопланктоноос үүссэн автохтон ба нуурын эргэн тойрны сав газрын дээд ургамлаас үүссэн аллохтон гэсэн үндсэн 2 хэсэгт хуваагддаг [Накай, 1993]. Органик бодисыг бүрдүүлж буй организмын биогеохимийн бүрэлдэхүүн харилцан адилгүй байдаг учраас нуурын хурдсанд агуулагдах нүүрстөрөгч ба азотын харьцаагаар органик бодисын эх үүсвэрийн тодорхойлдог [Krishnamurthy et al. 1993; Ishiwatary et al. 1992]. Үүнд: эх газрын ургамлын органик нүүрстөрөгч ба азотын харьцаа (TOC/TN) харьцангуй өндөр 20-40 орчим [Matsumoto et al. 2003] байдаг бол планктон замгийн хувьд уг харьцаа 6-11 байдаг [Прокопенко и др 2001; Вильямс и другие 1993]. 


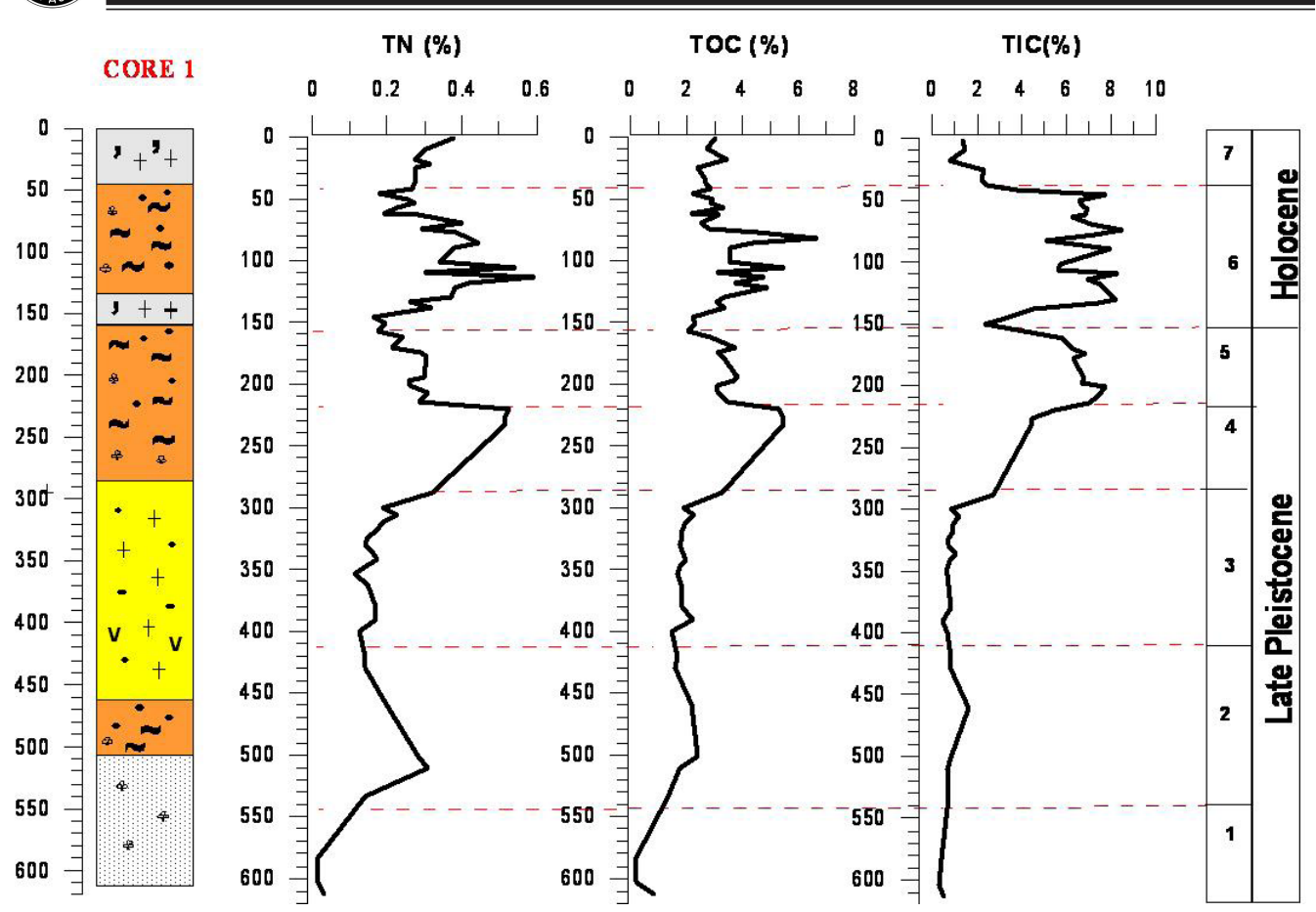

Зураг 4. Цөмрөг 1. Доод нуурын хурдасын нийлбэр азот, органик нүүрстөрөгч болон органик бус нүүрстөрөгчийн тархалтын муруй

Доод нуурын хурдасын цөмрөгийн дээд хэсгийн элс болон наангийн нимгэн үенцэр бүхий элсэрхэг зануу, зануулаг наангийн үенд TOC/TN харьцаа дунджаар 11 орчим байгаа нь органик бодис нь голдуу аминхүчил болон протейны өндөр агууламж бүхий автохтон гарал үүсэлтэй болохыг харуулна. Харин цөмрөгийн доод хэсгийн нарийн ширхэгт элсний үенд тогтоогдсон ТOC/TN харьцангуй өндөр (16-28) харьцаа нь тухайн үеийн хурдас хуримтлалд эх газрын ургамлаас үүсэлтэй аллохтон органик бодис зонхилж байгааг илтгэж байна.

\section{ХЭЛЭЛЦҮҮЛЭГ}

Байгал, Хөвсгөл болон бусад эх газрын нуурын хурдасын судалгаагаар хурдсанд агуулагдаж буй нүүрстөрөгч болон азотын нийлбэр агуулгыг (TOC, TN) байгалийн үржил шимийн индекс хэмээн үзэж эртний уур амьсгалын өөрчлөлтийн шалгуур үзүүлэлт болгон ашигладаг [Prokopenko et al. 2003; Matsumoto et al.2003].

Үүнд: органик нүүрстөрөгч ба азотын нийлбэр агуулгын өндөр үзүүлэлт нь мөстлөг хоорондын дулаан уур амьсгалыг харуулж байхад бага үзүүлэлт нь мөстлөгийн хүйтэн уур амьсгалыг тус тус илэрхийлдэг байна. Харин хүхрийн агууламж нь хурдас хуримтлалын орчны исэлдэн -ангижрах нөхцөлийг илэрхийлдэг учраас нуурын усны эрдэсжилт болон усны түвшний хэлбэлзлийн гэрч болгон үздэг [Накай, 1993]. Мөн Хөвсгөл нуурын хурдасын судалгаагаар TS өгөгдөл нь нуурын хурдас хоорондын усны сульфатын найрлагатай өндөр эерэг хамаарал үүсгэдэг бөгөөд голоцены дулаан уур амьсгалын нөхцөлд сульфатын давсны агуулга бага, харин хожуу плейстоцены мөстлөгийн хүйтэн үед түүний агууламж өндөр байгаа нь тогтоогдсон байдаг [Fedotov et al.2004]. Иймээс бид Доод нуурын 
хурдасын ТОС, TN, TS болон TC, TIC өгөгдөлүүдийг байгаль орчны өөрчлөлт, тэдгээрээс үүдэлтэй нуурын усны түвшний хэлбэлзлэлийг тогтооход шалгуур үзүүлэлт болгон авч хэрэглэсэн бөгөөд тэдгээрийн хурдасын гүний дагуух тархалтын онцлогт үндэслэн цөмрөг 1-ийн хэмжээнд маш тод ялгарсан 2 өөр хурдас хуримтлалын орчны хүрээнд 7 дэд үеийг ялгасан болно (зураг 4 ба 5).

TOC \%

TC \%

nc \%

TS \%

CIN

$0 \quad 2040 \quad 60 \quad 80$

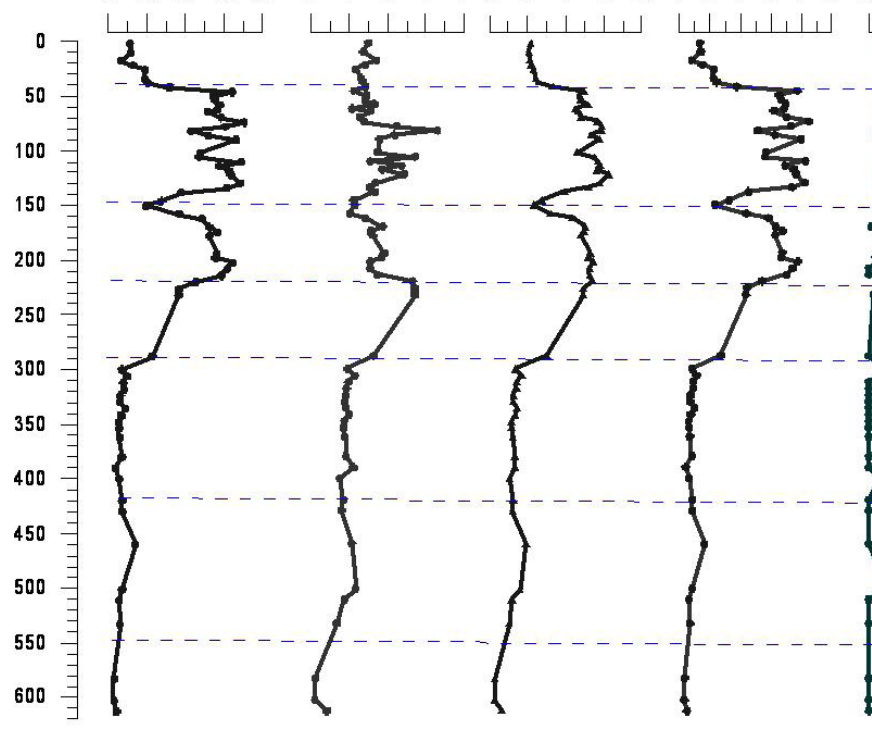

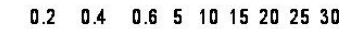

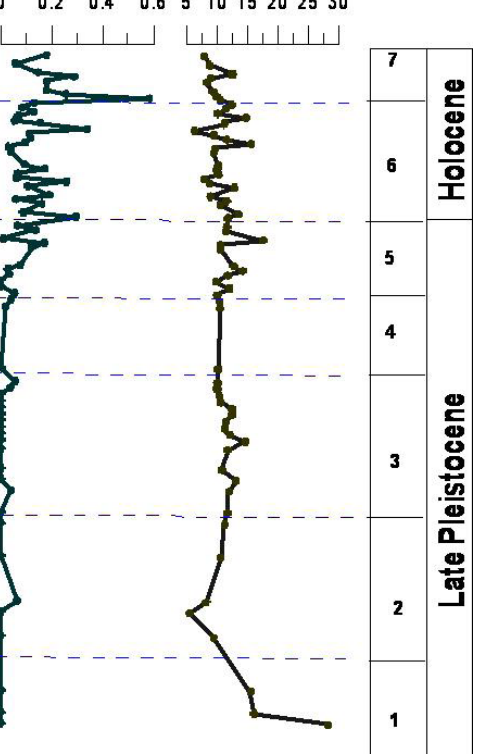

Зураг 5. Цөмрөг 1. Доод нуурын хурдасын карбонат кальизи, органик нүүрстөрөгч, нийлбэр нҮҮрстөрөгч, органик бус нүҮрстөрөгч, нийлбэр хүхэр болон органик нүҮрстөрөгч ба азотын харьйаa

1-p дэд үе буюу цөмрөгийн 620550 см интервалд ТОС, TN болон ТICийн агуулга хамгийн бага, харин ТОС/ TN харьцаа хамгийн их (16-28) байгаатай холбоотойгоор тухайн цаг үед уур амьсгал хүйтэн, усны түвшин бага, нуурын болон сав газрын биологийн үржил шим бага, органик бодисын бүрэлдэхүүнд эх газраас ҮҮдэлтэй аллохтон органик бодис зонхилж байсан гэж үзэж байна. Харин 2-р дэд үе дэх (550-420 см) хурдсанд агуулагдах ТОС, $\mathrm{TN}-$ ын агуулга өмнөх үетэй харьцуулбал бараг 3-4 дахин нэмэгдэж TOC/TN харьцаа 4 хүртэл буурч байгааг үндэслэн дулаан, чийглэг уур амьсгал зонхилж усны түвшин нэмэгдэж байсан гэж үзэж болно. 3-р дэд үе буюу 420-300 см интервалд нуурын усны түвшин бага хэмжээгээр буурсан нь ТОС,
TN-ы агуулгын хэлбэлзлээс харагдана. 4-p дэд үеэс (300-220 см) эхлэн бидний судалгаанд эртний уур амьсгал, байгаль орчны өөрчлөлтийн шалгуур үзүүлэлт болгон авсан TOC, TN, TC, TIC зэрэг өгөгдөлүүдийн агуулга бүгд нэмэгдэж байгаа нь уур амьсгалын дулаарлаас үүдэн нуурын усны түвшин дээшилж, биологийн үржил шим нэмэгдээд зогсохгүй нууранд орж ирэх хайлсан мөсний хэмжээ нэмэгдэж байсныг харуулна. Харин уг дэд үений хэмжээнд TS-ийн агуулга өмнөх үеүдийн хэмжээнд байгааг үндэслэн нуурын усны эрдэсжилт нэг их өөрчлөгдөөгүй гэж үзэж болно. 5-р дэд үе буюу 220-150 см интервалд TOC, TN агуулга буурах хандлагатай, харин карбонат кальци, нийлбэр хүхэр болон нийлбэр нүүрстөрөгчийн агуулга 
харьцангуй өндөр байгаа нь нуурын усны түвшин бага, эрдэсжилт өндөр байсныг илтгэнэ. 6-р дэд үений (160-42 см) хэмжээнд органик нүүрстөрөгч болон азотын агуулга хамгийн их хэмжээтэй, мөн органик бус нүүрстөрөгч, карбонат кальцийн эзлэх хувь хэмжээ эрс нэмэгдэж байгаагаас үүдэн уур амьсгал эрс дулааран усны түвшин ихээр нэмэгдэн, хайлсан мөс их хэмжээний ус болон карбонат хэмхдэсүүд нуурандзөөгдөн орж ирсэн хэмээн үзэж болно. 7-р дэд үений (43-0 см) хэмжээнд ТОС, TN, TC, TIC болон $\mathrm{CaCO}_{3}-$ ийн агуулга эрс буурч байгаа нь уур амьсгал дахин сэрүүсч нуурын усны түвшин буурч байсныг илтгэнэ. Хурдсанд агуулагдах хүхрийн агуулга мөн буурч байгаа нь магадгүй энэ үеэс эхлэн Доод нуурын ус цэнгэгшиж эхэлсэнийг харуулж байна.

\section{ДУГНЭЛТ}

1Доод нуурын хэмжээнд сүүлийн 1400 жилийн хугацаанд хоорондоо эрс тэс ялгаатай 2 өөр (хожуу плейстоцены хүйтэн болон голоцены дулаан) уур амьсгалын нөхцөлд хурдас хуримтлал явагдсан болохыг хурдасын биогеохимийн шинжилгээний дүнгээр илрүүлсэн. Энэ хугацаанд нуурын усны түвшний дараалсан 2 удаагийн нэмэгдэлт болон 2 удаагийн бууралтын үеийг тус тус ялгасан. Эдгээрийн дотроос нуурын усны түвшний эхний өсөлт нь хожуу плейстоценоос голоценд шилжих шилжилтийн үед (290-220 см) харин дараагийн нэмэгдэлт нь голоцены эхэн үед (160-43 см) тохиосон байна.

2Доод нуурын хурдасын нарийн ширхэгтэй элсний $\mathrm{Ye}$ болон наангилаг зануу нь органик нүүрстөрөгч болон азотын нийлбэр агуулга харьцангуй багатай (дунджаар 0,19-2,36\% ба 0,01-0,21\%), харин элсэрхэг зануу болон зануулаг наангийн хувьд тэдгээр нь нилээд өргөн хэлбэлзэлтэй $(1,32-6,59 \%$ ба $0,14-0,51 \%)$ байгаa зүй тогтолыг илрүүлсэнээс гадна голоцены дулаан үед органик бодисын бүрэлдэхүүнд автохтон гарал үүсэл бүхий органик бодис зонхилж байгаа бол хожуу плейстоцены үеийн хурдсанд автохтон бодисоос гадна аллохтон бодисын оролцоо ихээхэн байгааг илрүүлсэн.

\section{ТАЛАРХАЛ}

Доод нуурын хурдасын цөмрөгийн дээжинд органик геохимийн шинжилгээг өндөр нарийвчлал бүхий багаж тоног төхөөрөмж дээр гүйцэтгэх боломж олгож өгсөн Кангвоны Үндэсний их сургуулийн Геологийн факультетын Профессор Дайко Чонг, Солонгосын Далай ба туйл судлалын хүрээлэнгийн доктор Лим Со нарт гүн талархал илэрхийлье. 


\section{Ашигласан бүтээлийн жагсаалт}

1. Выхристюк, Л. А., 1980, Органическое вещество донных осадков Байкала: Новосибирск, с. 80-95.

2. Вильямс, Д.Ф., Карбанов, Е.В.,Прокопенко, А.А., и др 2001. Комплексные исследования позднемиоцеплейстоценовых донных отложений озера Байкал- основа палеоклиматических реконструкций и диатомовой биостратиграфии: геология и геофизика №. $42,1-2$, c. $35-47$.

3. Дорофеюк Н.И., Тарасов П.Е. 1998. Растительность и уровни озер севера Монголии за последние 12500 лет, по данным палинологического и диатомового анализов.// Cmpaтиграфия, геологическая корреляиия. Т.6.№1. с.73-87

4. Накай Нобияки и Муцуо Кояма, 1993. Реконструкция палеосреды по неорганическим компонентам, $\mathrm{C} / \mathrm{N}$ отношению и изотопному отношению углерода на примера керна 1400 метровой скважины на озера Бива: История Озера Бива, с 131-143

5. Matsumoto, G. In., Chizu Fujimura, Koji Minoura, Takamatsu, N., Tetsuo Takemura, Susumu Hayashi, Koji Shichi and Kawai, T., 2003. Paleoenvironmental Changes in the Eurasian Continental Interior during the last 12 Million Years Derived from Organic Components in Sediment Cores (BDP-96 and BDP-98) from Lake Baikal: Lake Baikal, p. 75-94.

6. Narantsesteg Ts., D. Tomurhuu Ts., Oyunchimeg, 2010. Late Pleistocene /Early Holocene Climate Conditions of Northern Mongolia Based on Carbon and Oxygen Stable Isotopes of Dood Lake Sediments. Abstract volume of the $8^{\text {th }}$ international Symposium on Environmental Processes of East Eurasia, Asian monsoon changes and interplay of high and low latitude climates, Kunming, China, November 7-9, p 13-16

7. Ц.Оюунчимэг, Д.Томорхуу, Ц.Наранцэцэг, Ховсгол нуурын сав газрын доровдогчийн хурдас хуримтлалын орчин, уур амьсгалын онцлогийг химийн судалгааны аргаар тодорхойлох нь ШУА-ийн ГЭБХ бутээл № 14, 2004, х 135-147

8. Krishnamurthy, R. V., Bhattacharya, S. K., Kusumgar, S., 1986. Paleoclimatic changes deduced from $13 \mathrm{C} / 12 \mathrm{C}$ and $\mathrm{C} / \mathrm{N}$ ratios of Karewa lake sediments, India: Nature 325. p. 150152.

9. Прокопенко А. А., Карабанов Е. Б., Кузьмин М. И., Вильямс Д. Ф. 2001. Причины раннего оледенения сибири при переходе от казанцевского климатического оптимума к зырянскому ледниковому периоду (результаты изучения донных осадков озера Байкал), Геология и геофизика, т. 42, 1-2, с. 64-75

10. Хосбаяр П. 2005 . Монгол орны Мезой ба Кайнозойн эриний эртний газар зүй, уур амьсгал. 120-128

11. Цэрэнсодном Ж. 2000. Монгол орны нуурын каталог (цэс), Улаанбаатар, х 116-117

12. Fedotov A.P., Chebykin E.P., Semenov M.Yu., Vorobyova S.S., Osipov E.Yu., Golobokova L.P., Pogodaeva T.V.,Zheleznyakova T.O., Grachev M.A. Tomurhuu D., OyunchimegTs., Narantsetseg Ts., Tomurtogoo O., Dolgikh P.T., Arsenyuk M. I., M. De Batist. Changes in the volume and salinity of Lake Khubsugul (Mongolia) in response to global climate changes in the upper Pleistocene and the Holocene // Palaeogeography, Palaeoclimatology, Palaeoecology. - 2004. - V. 209. - P. 245-257.

13. Krivonogov S. K., Sheinkman V. S., Mistruykov A. A. 2005. Stages in the development of the Darhad dammed lake (Northern Mongolia) during the Late Pleistocene and Holocene. Quaternary International, 136, 83-94.

14. Tomurhuu, D., Chebykin, E.P., Fedotov, A.P., Ts.Oyunchimeg., S.S.Borobyova and 
Ts.Narantsetseg 2003a. Lake Hovsgol's sediment geochemistry. Abstract volume of "Baiksed-2”, International workshop on sedimentary processes in large Lakes, 17-18 January 2003, Gent, Belgium, p. 56

15. Watanabe, H. Naraoka, M. Nishimura, M. Kinoshita and T. Kawai, 2003. Glacial-interglacial changes in organic carbon, nitrogen and sulfuraccumulation in Lake Baikal sediment over the past 250 kyr. Geochemical Journal, Vol. 37, p 493 - 502 